\title{
PELATIHAN PENULISAN KARYA ILMIAH UNTUK PENINGKATAN PROFESIONALISME GURU
}

\section{WRITING TRAINING OF SCIENTIFIC WORKS FOR IMPROVING PROFESSIONALISM FOR TEACHERS}

\author{
${ }^{1)}$ Kasiyan, ${ }^{2)}$ B Muria Zuhdi, ${ }^{3)}$ Zulfi Hendri, ${ }^{4)}$ Aran Handoko, ${ }^{5}$ Maraja Sitompul \\ ${ }^{1,2,3,4,5)}$ Program Studi Pendidikan Seni Rupa, Fakultas Bahasa dan Seni, Universitas Negeri Yogyakarta \\ Jalan Colombo, No. 1 Karangmalang, Yogyakarta, Indonesia \\ kasiyan@uny.ac.id
}

\begin{abstract}
ABSTRAK
Salah satu masalah dalam pengembangan profesionalisme guru selama ini adalah terkait dengan persoalan penulisan dan publikasi karya ilmiah melalui jurnal ilmiah. Tujuan kegiatan ini adalah untuk memberikan pelatihan tentang penulisan karya ilmiah terutama untuk jurnal ilmiah. Pelatihan ini diikuti oleh para guru dan siswa SMKN 1, Kalasan, Sleman, Yogyakarta, sebanyak 25 orang. Metode yang digunakan adalah 1) pemberian pengetahuan teoretis dan praktis tentang penulisan karya ilmiah 2) penugasan pembuatan karya tulis ilmiah, 3) penyerahan karya tulis ilmiah dan 4) publikasi karya tulis ilmiah di jurnal. Hasil kegiatan ini adalah : Pertama, semua peserta kegiatan pelatihan ini sangat antusias, bersemangat, dan mempunyai motivasi yang tinggi mengikuti pelaksanaan kegiatan pelatihan penulisan karya ilmiah. Kedua, peserta kegiatan yang berhasil membuat karya ilmiah sejumlah 5 orang atau $20 \%$ dari 25 peserta. Ketiga, kualitas artikel termasuk kategori cukup baik.
\end{abstract}

Kata kunci : Pelatihan, Penulisan karya Ilmiah, Guru

\section{ABSTRACT}

One of the problems in the development of teacher professionalism has been related to the issue of writing and publishing scientific work through scientific journals. The purpose of this activity is to provide training on scientific writing, especially for scientific journals. The training was attended by teachers and students of SMK 1, Kalasan, Sleman, Yogyakarta, as many as 25 people. The methods used are 1) giving theoretical and practical knowledge about scientific writing 2) assigning scientific writing work, 3) submitting scientific papers and 4) publishing scientific papers in journals. The results of this activity are: First, all participants of this training activity were very enthusiastic, enthusiastic, and had high motivation to take part in the implementation of scientific writing training activities. Secondly, the participants who succeeded in making scientific work were 5 people or $20 \%$ of the 25 participants. Third, the quality of the articles is quite good

Keywords : Training, Writing Scientific work, Teacher

Submited : 11 Agustus $2018 \quad$ Revision : 13 November 2018 Accepted : 16 November 2018

\section{PENDAHULUAN}

Salah satu titik strategis yang selalu menjadi catatan kritis terkait dengan peningkatan kualitas pendidikan adalah erat berkaitan dengan dimensi guru atau pendidik. Milakovich (2005) mengungkapkan, "Teachers are an important factor, and it is important that they feel ownership in educational processes to ensure quality". Pandangan yang senada juga disampaikan oleh Sothirak, Wade \& Hong (2012) : "The most important school-based factor in a child's education is teacher quality". Demikian strategisnya peran guru dalam 
konstelasi pendidikan, disebabkan guru menduduki posisi dan peran sebagai salah satu ujung tombak dalam praksis pelaksanaan pendidikan. Apabila ditemukan masalah pada sekolah, siswa dan bahkan dalam pendidikan nasional maka guru seringkali dianggap paling bertanggung jawab (Usman, 1995). Wong \& Cheng(1995) mengatakan : "Most of the reports go on to stress the inextricable link between the quality of education and the quality of the teaching service".

Mengingat demikian strategisnya posisi dan peran guru sebagai ujung tombak sekaligus garda terdepan terhadap keberhasilan pendidikan, maka keberadaannya harus didukung kompetensi. Kompetensi guru dapat diartikan sebagai kebulatan pengetahuan, keterampilan, maupun sikap yang ditampilkan dalam bentuk perilaku cerdas dan penuh tanggung jawab yang dimiliki seorang guru dalam menjalankan profesinya (Mulyasa, 2008; Fahdini, Mulyadi, Suhandani, \& Julia, 2014). Sesuai dengan yang diamanatkan pada Pasal 28 Peraturan Pemerintah Nomor 19 Tahun 2005, tentang Standar Nasional Pendidikan, pada ayat 1 disebutkan bahwa pendidik harus memiliki kualifikasi akademik dan kompetensi sebagai agen pembelajaran, sehat jasmani dan rohani, serta memiliki kemampuan untuk mewujudkan tujuan pendidikan nasional. Kompetensi yang dinyatakan pada ayat satu, disebutkan pada ayat 3 meliputi: kompetensi pedagogik, kompetensi kepribadian, kompetensi profesional, dan kompetensi sosial. Penguasaan empat kompetensi tersebut mutlak harus dimiliki setup guru untuk menjadi tenaga pendidik yang profesional. Terkait dengan istilah profesionalisme, sesuai dengan UU No. 14 Tahun 2005 tentang Guru dan Dosen, maknanya adalah sebagai pekerjaan atau kegiatan yang dilakukan oleh seseorang dan menjadi sumber penghasilan kehidupan yang memerlukan keahlian, kemahiran, atau kecakapan yang memenuhi standar mutu atau norma tertentu serta memerlukan pendidikan profesi. Amanah undang-undang sebagaimana dimaksud, menegaskan bahwa betapa pada hakikatnya, secara imperatif setiap pendidik dituntut untuk selalu belajar bagaimana menjadi guru yang profesional dan memiliki kompetensi yang mumpuni (Mansyur \& Akidah, 2018).

Untuk mendukung tercapainya profesionalisme itulah guru memerlukan pembinaan dan pengembangan profesi secara utuh dan berkelanjutan (Suyanto \& Jihad, 2013; Noorjannah, 2014). Salah satu upaya yang cukup menjanjikan bagi pengembangan keprofesian guru itu adalah melakukan kegiatan publikasi ilmiah. Perihal pentingnya tentang publikasi ilmiah bagi para pendidik ini bahkan telah menjadi kebijakan yang ditegaskan dalam Peraturan Menteri Pendayagunaan Aparatur Negara dan Reformasi Birokrasi Nomor 16 Tahun 2009, yang mengatur Jabatan Fungsional Guru dan Angka Kreditnya. Selain dari unsur utama dari kegiatan mengajar, guru juga harus memenuhi unsur pengembangan profesi melalui publikasi kegiatan ilmiah atau karya inovatif. Guru yang akan naik pangkat harus mengumpulkan angka kredit dari publikasi ilmiah atau karya inovatif sebagai berikut : Untuk naik pangkat dari III/b ke III/c 4 poin, III/c dke III/d 6 poin, III/d ke IV/a sebanyak 8 poin. Sementara itu, guru yang naik pangkat dari IV/a ke IV/b harus mengumpulkan angka kredit 10 poin.

Di luar alasan yang terkesan amat pragmatis tersebut, sejatinya ada beberapa argumentasi yang lebih mendasar, mengapa guru harus memiliki kemampuan menulis. Pertama, dunia guru adalah dunia literasi: membaca, menulis, dan mengajar. Guru yang mampu menulis dengan baik, maka ia adalah pembaca dan pendengar yang baik. Guru penulis memiliki keilmuan yang terbarukan (renewable) sehingga 
akan lebih potensial tampil sebagai guru profesional sejati. Kedua, posisi dan peran guru sebagai pendidik itu sejatinya bukan hanya bagi para siswanya di sekolah, melainkan juga bagi masyarakat dalam artian yang luas (Sudarsana, 2016; Schulz, Ainley, \& Fraillon, 2016; Sudrajat, 2011; Perry, 2002). Ketiga, menulis adalah ajang atau media berbagi gagasan, yang sangat penting maknanya bagi pengembangan ilmu pengetahuan dan kebudayaan. Hal ini sebagaimana disampaikan oleh Paulo Coello, bahwa "Writing means sharing. It's part of the human condition to want to share things-thoughts, ideas, opinions" (Brandon \& Brandon, 2016).

Secara terminologi, konsep karya tulis ilmiah itu menginduk pada pengertian karya ilmiah secara umum. Yang membedakan hanyalah, kalau karya tulis ilmiah itu disampaikan melalui media atau sarana tertulis atau tulisan, sementara karya ilmiah yang lainnya ada yang cara penyampaiannya tidak atau bukan melalui tulisan, melainkan secara lisan (oral). Karya ilmiah itu sendiri yang dalam bahasa Inggrisnya diistilahkan sebagai scientific paper, dapat dimaknai sebagai sebentuk laporan tertulis dan diterbitkan yang memaparkan hasil penelitian atau pengkajian yang telah dilakukan oleh seseorang atau sebuah tim dengan memenuhi kaidah dan etika keilmuan yang dikukuhkan dan ditaati oleh masyarakat keilmuan.

Karya tulis ilmiah sering juga disebut "tulisan akademis" (academic writing) (Livnat, 2012), karena biasa ditulis oleh kalangan kampus perguruan tinggi, dosen dan mahasiswa. Karya tulis ilmiah berfungsi sebagai sarana untuk mengembangkan ilmu pengetahuan dan teknologi berupa penjelasan (explanation), prediksi (prediction), dan pengawasan (control).

Adapun makna atau fungsi dari keberadaan karya tulis ilmiah ini, dalam konteks kaitannya dengan proses pengembangan keilmuan, dapat dikatakan sangat penting dan strategis maknanya, terutama dalam rangka penyebarluasan informasi atas temuan atau gagasan pengetahuan baru yang ada di sekitar kita. Day \& Gastel (2006), dalam kaitan ini pernah menyampaikan, yakni "Communication to other scientists ensures that new findings become part of a growing body of publicly available knowledge that information about how we understand the world around us".

Manakala ditinjau dari perspektif jenisnya, maka dapat disampaikan bahwa yang dinamakan karya tulis ilmiah itu sangat banyak, di antaranya adalah berupa laporan penelitian, makalah, atau artikel jurnal.Kemudian karya tulis ilmiah juga dibedakan antara yang ilmiah dan populer. Istilah "populer" ini tidak dalam pengertian tidak ilmiah, tetapi lebih terkait dengan pilihan atau gaya bahasa berikut sistematika penulisan yang dipergunakannya yang tidak terlalu ilmiah atau baku. Hal ini sebagaimana makna dari istilah "populer" Dalam Kamus Bahasa Indonesia, disebutkan bahwa kata "populer" berarti dikenal dan disukai orang banyak (umum).

Adapun, jika dilihat dari struktur sistematikanya, karya tulis baik dalam kategori ilmiah maupun ilmiah populer, secara umum mempunyai tata kelola kerangka berifikir, yang di dalamnya mencakup pendahuluan atau pengantar, diskusi atau pembahasan, dan penutup. Hanya dalam konteks karya tulis ilmiah yang non populer, biasanya juga disertai dengan kelengkapan berupa abstrak (ditulis sebelum pengantar), dan metode (sesudah pengantar), dan juga daftar pustaka.

Adapun yang menjadi persoalan kemudian adalah bahwa kemampuan guru terkait dengan publikasi ilmiah sampai saat ini tergolong rendah, bahkan akhirnya menjadi salah satu hambatan utama dalam pengajuan kenaikan pangkat. Data pada tahun 2015 misalnya, ada lebih dari 
800.000 guru terancam tidak bisa naik pangkat, yang disebabkan ketidakmampuan guru dalam membuat karya ilmiah hasil penelitian (Koran Sindo, 4 Juli 2015). Berdasarkan data hasil diskusi dengan para guru di SMKN 1 Kalasan, Sleman, Yogyakarta, menunjukkan bahwa persoalan terkait dengan rendahnya kompetensi publikasi ilmiah tersebut, juga menjadi permasalahan yang cenderung hampir sama.

Berdasarkan masalah tersebut maka setelah kegiatan ini diharapkan para guru di SMKN 1 Kalasan, Sleman, Yogyakarta mempunyai pengkayaan dan peningkatan kompetensi profesional khususnya dalam kemampuan menulis artikel ilmiah dan mempublikasikannya melalui jurnal ilmiah.

\section{METODE}

Kegiatan pengabdian kepada masyarakat ini dilaksanakan di SMKN 1 Kalasan, Sleman, Yogyakarta.

Metode pelaksanaan kegiatan berupa : 1) Metode ceramah khususnya terkait dengan pemahaman terhadap paradigma perihal karya tulis ilmiah; proses penyusunan karya tulis ilmiah; dan proses publikasi karya tulis ilmiah pada jurnal ilmiah; dan 2) Metode pemberian tugas terkait dengan pembuatan karya tulis ilmiah dan disertai dengan pendampingan sampai siap publikasi di jurnal ilmiah.

Pelaksanaan kegiatan ini melibatkan kelompok sasaran para guru di SMKN 1 Kalasan, Sleman, Yogyakarta ini. Sekolah ini berjarak sekitar $12 \mathrm{Km}$ dari kampus UNY. SMKN 1, Kalasan, Sleman, Yogyakarta,adalah SMK yang berbasis keilmuan Seni Kriya dan Pariwisata, yang mempunyai 7 jurusan, yang dibagi ke dalam dua kelompok, yakni 5 jurusan berbasis keilmuan Seni Kriya, yakni Kriya Tekstil, Kirya Keramik, Kriya Logam, Kriya Kayu, Kriya Kulit, dan 2 bidang yang berbasis keilmuan di luar seni, yakni
Akomodasi Hotel, dan Jasa Boga. Jumlah guru yang ada di sekolah ini sebanyak 93 orang. Kegiatan ini diikuti 25 guru guru SMKN 1 Kalasan, Sleman, Yogyakarta.

\section{HASIL DAN PEMBAHASAN}

Indikator keberhasilan kegiatan pelatihan dari sisi proses ini, juga tampak dari hasil evaluasi yang didasarkan pada taraf respons peserta, mengenai kebermanfaatan kegiatan pelatihan yang diikuti, dengan dengan empat kategori yakni, sangatbermanfaat (81\%), bermanfaat (19), kurang bermanfaat (0), dan tidak bermanfaat (0), sebagaimana dapat dilihat pada tabel berikut.

Tabel 2. Respons Peserta Mengenai Kebermanfaatan Kegiatan Pelatihan

\begin{tabular}{lllc}
\hline No. & Interval & \multicolumn{1}{c}{ Kategori } & Persentase \\
\hline 1. & $\begin{array}{l}86 \%- \\
100 \%\end{array}$ & $\begin{array}{l}\text { Sangat } \\
\text { bermanfaat }\end{array}$ & $81 \%$ \\
\hline 2. & $\begin{array}{l}66 \%- \\
85 \%\end{array}$ & Bermanfaat & $19 \%$ \\
\hline 3. & $\begin{array}{l}36 \%- \\
65 \%\end{array}$ & $\begin{array}{l}\text { Kurang } \\
\text { bermanfaat }\end{array}$ & 0 \\
\hline 4. & $0 \%-35 \%$ & $\begin{array}{l}\text { Tidak } \\
\text { bermanfaat }\end{array}$ & 0 \\
\hline
\end{tabular}

Produk karya tulis ilmiah yang dihasilkan dapat disampaikan, yakni bahwa dari sisi kuantitas atau jumlah karya tulis yang berhasil diselesaikan oleh para guru, dapat dikategorikan kurang, sebab hanya terkumpul 5 orang atau $20 \%$ dari 25 peserta yang ada. Sementara itu terkait dengan sisi kualitasnya, karya tulis yang dihasilkan tersebut termasuk dalam kategori cukup baik. Indikator dari kualitas yang cukup baik tersebut, diantaranya tampak dari keterbatasan terkait dengan pengelolaan kerangka berfikir, penggunaan bahasa Indonesia yang baik dan benar, kaidah penulisan atau pengutipan sumber, serta ketaatasasan terhadap gaya selingkung jurnal. 
Berdasarkan data hasil berupa produk artikel ilmiah dari kegiatan pelatihan, baik dari sisi kuantitas maupun kualitas tersebut, dapat disampaikan bahwa semakin meneguhkan betapa kompetensi terkait dengan penulisan publikasi karya ilmiah untuk jurnal tersebut, terutama lagi dalam konteks guru di lingkungan pendidikan seni, sebagaimana yang menjadi fokus kegiatan ini semakin terverifikasi. Adapun salah satu faktor penyebabnya yang kiranyan amat krusial dan mendesak untuk dipecahkan adalah, orientasi mentalitas kesadaran (mindset) berkeilmuan yang selama ini dijalani terutama di lingkungan lingkungan kelembagaan pendidikan seni, yang lebih berarusutamakan domain praktik berkarya seni, dibandingkan dengan menulis dan atau meneliti. Persoalan tersebut bukan hanya ada di kalangan pendidik seni di jenjang sekolah menengah, melainkan juga relatif cenderung menjadi fenomena klasik yang hampir sama di jenjang pendidikan yang lebih tinggi, misalnya di kampuskampus seni. Hal ini dikatakan Soedarsono (2001), bahwa betapa pendidik seni di kampus-kampus itu lebih banyak berurusan dengan kegiatan parktik mencipta atau berkarya seni, jika dibandingkan dengan menulis atau meneliti seni. Arus utama dunia dan keilmuan seni sampai hari ini, masih meneguhkan dan meyakini bahwa yang namanya dunia seni itu, seolah tak memerlukan dukungan referensi yang berbasis literasi konseptual atau teoretik, yang diwujudkan misalnya melalui pelbagai kegiatan menulis dan meneliti. Padahal dalam perspektif ideal, mestinya tidaklah demikian adanya. Dunia dan keilmuan seni, sejalan dengan dunia dan keilmuan yang lain, keutuhan eksistensinya senantiasa memerlukan toangan atau penyangga, baik di tingkat teoretis dan juga praksis.Dari sinilah akhirnya, dunia dan keilmuan seni berikut pendidiknya menjadi demikian tampak secara laten dan terus-menrus menderita kemiskinan wacana (lack of discourse) yang seolah tak pernah habis-habisnya, dan karenanya amat perlu bahkan mendesak untuk dicarikan kemungkinan alternatif pencerahannya.

\section{SIMPULAN}

Hasil kegiatan dapat disimpulkan dari sisi proses, termasuk dalam kategori baik, dengan indikator di antaranya kehadiran peserta pelatihan yang mencapai $100 \%$, semua peserta tampak sangat antusias, bersemangat, dan mempunyai motivasi yang sangat tinggi mengikuti pelaksanaan kegiatan ini. fenomena tersebut, di antaranya disebabkan oleh tingkat kebutuhan atau kepentingan para guru terkait adanya kaharusan kepemilikan kompetensi penulisan berikut publikasi karya ilmiah, sebagai salah satu pilar amat penting bagi peningkatan profesionalisme mereka. Kemudian dari sisi hasil produk, yakni berupa karya tulis ilmiah yang dihasilkan, dapat disampaikan adalah kurang, baik dari sisi kuantitas dan juga kualitasnya. Dari sisi kuantitas atau jumlah karya tulis yang berhasil diselesaikan dan diserahkan kepada tim pelaksana kegiatan pengabdian kepada masyarakat ini, yakni hanya berjumlah 5 buah atau 20\% dari 25 peserta. Dari sisi kualitasnya dapat disampaikan bahwa, karya tulis yang dihasilkan dalam kategori cukup baik. Ada beberapa kekurangan yang masih perlu mendapatkan perhatian terkait karya tulis yang dihasilkan, misalnya adalah terkait dengan cara pengembangan dan penataan kerangka beroikir, pentingnya memperhatikan cara penulisan dengan menerapkan kaidah pemakiaan bahasa Indonesia yang baik dan benar; pentingnya memperhatikan dan menerapkan gaya selingkung yang dimiliki oleh jurnal.Di samping juga pentingnya memperhatian cara penggunaan rujukan referensi yang relevan, kredibel, dan mutakhir. 


\section{DAFTAR PUSTAKA}

Brandon, L. and Brandon, K. (2016). Paragraphs and Essays: With Integrated Readings. Boston, United States: Cengage Learning.

Day, RA. \& Gastel B. (2006). How to Write and Publish A Scientific Paper. $6^{\text {th }}$. New York: Cambridge University Press.

Fahdini, R.. Mulyadi, E., Suhandani, D., \& Julia, J. (2014). Identifikasi Kompetensi Guru sebagai Cerminan Profesionalisme Tenaga Pendidik di Kabupaten Sumedang. Mimbar Sekolah Dasar, 1 (1),3342.

Doi: http://dx.doi.org/10.17509/mimbar -sd.v1i1.1362.

Koran Sindo, 4 Juli 2015. "800.000 Guru terancam tidak bisa naik pangkat".

Laporan Dies Natalis ke-52 UNY Tahun 2016. Yogyakarta: Universitas Negeri Yogakarta.

Livnat, Z. (2012). Dialogue, Science and Academic Writing. Amsterdam, Netherland: John Benjamins Publishing.

Mansyur, U. \& Ihramsari Akidah, I. (2018). Peningkatan Kompetensi Profesional Guru MTs di Padanglampe Kabupaten Pangkep melalui Pelatihan Penulisan Karya Tulis Ilmiah. Jurnal Pengabdian dan Pemberdayaan Masyarakat, 2 (2), 273-278. Doi: 10.30595/jppm.v2i2.2589.

Milakovich, M. (2005). Improving Service Quality in The Global Economy: Achieving High Performance in Public and Private Sectors. Second Edition. Boca Raton, Florida: CRC Press.

Mulyasa, E. (2008). Standar Kompetensi dan Sertifikasi Guru. Cetakan Ke3. Bandung: Remaja Rosdakarya.
Noorjannah, L. (2014). Pengembangan Profesionalisme Guru melalui Penulisan Karya Tulis Ilmiah bagi Guru Profesional Di SMA Negeri 1 Kauman Kabupaten Tulungagung. Jurnal Humanity, 10, (1), 98-114.

Peraturan Menteri Pendayagunaan Aparatur Negara dan Reformasi Birokrasi Nomor 16 Tahun 2009.

Peraturan Menteri Pendidikan Nasional Nomor 16 Tahun 2007 tentang Standar Kualifikasi Akademik dan Kompetensi Guru.

Peraturan Pemerintah Nomor 19 Tahun 2005, tentang Standar Nasional Pendidikan.

Perry, R. (2002).Teaching Practice: A Guide for Early Childhood Students. London: Routledge.

Schulz, W., Ainley, J., and Fraillon, J. (2016). IEA, International Civic and Citizenship Education Study 2016 Assessment Framework. Salmon Tower Building, New York City: Springer.

Soedarsono, R.M. (2001). Metodologi Penelitian Seni Pertunjukan dan Seni Rupa. Bandung: Masyarakat Seni Pertunjukan Indonesia.

Sothirak, P., Wade, G., \& Hong, M. (eds.). (2012). Cambodia: Progress and Challenges Since 1991. Singapura: Institute of Southeast Asian Studies.

Sudarsana, I.K. (2016). Pemikiran Tokoh Pendidikan dalam Buku Lifelong Learning: Policies, Practices, and Programs (Perspektif Peningkatan Mutu Pendidikan di Indonesia). Jurnal Penjaminan Mutu, 2 (2). 44-53.

Doi: http://dx.doi.org/10.25078/jpm.v2i 2.71 . 
Sudrajat, A. (2011). Mengapa Pendidikan

Karakter? . Jurnal Pendidikan

Karakter, 1. 47-58. Doi: http://dx.doi.org/10.21831/jpk.v1i1 .1316

Suyanto \& Jihad, A. (2015). Menjadi Guru Profesional: Strategi Meningkatkan Kualifikasi dan Kualitas Guru di Era Global. Surabaya: Erlangga.

Undang-undang Nomor 14 Tahun 2005 tentang Guru dan Dosen.

Usman, M.U. (1995). Menjadi Guru Profesional. Bandung: Remaja Rosda Karya.

Wong, K.C. \& K.M. Cheng. (1995). Educational Leadership and Change: An International Perspective. Hong Kong: Hong Kong University Press. 